\title{
Teacher's problems and solutions in implementing student-centered learning in SMAN Bali Mandara Singaraja
}

\author{
Putu Erna Adnyani ${ }^{1}$, I Putu Ngurah Wage Myartawan ${ }^{2}$, I Nyoman Pasek Hadi Saputra ${ }^{3}$ \\ ${ }^{1,2,3}$ English Education, Foreign Language Department, Universitas Pendidikan Ganesha Singaraja, Indonesia \\ *) correspondence: putuerna13@gmail.com
}

\begin{abstract}
This qualitative descriptive study aimed at analyzing teachers' problems and solutions in implementing Student-centered Learning. This study involved an English teacher in SMA N Bali Mandara Singaraja. The instruments of this study consisted of voice recorder, field notes, interview guide, and researcher as the main instrument. The obtained data were analyzed using Miles and Huberman (1994) theory which consisted of data collection, data reduction, data display and conclusion drawing/verification. The results showed that the teacher's problems included problems caused by students, teacher, and facilities to support learning. The teacher' solutions to solve the problems were by identifying the students' ability, motivating students personally, doing the class management well, using "stick talking" game to lead students to ask a question, instructed students to find more resources on the internet or library, giving a reward, instructed students to revise their planning when it was not meeting the minimum score before mobilizing them to the other group or permitting them to choose individual task based on their interest, grouping students evenly based on the identification result, scheduling and instructing them to do a discussion with their friend before consulting their project to the teacher and the last borrowing tools from the school facilities section and rotating the tool usage.
\end{abstract}

Keywords: student-centered learning (SCL); teachers' problem; teachers' solution; 2013 curriculum

\section{INTRODUCTION}

Student-centered learning (SCL) is a learning approach that can increase the effectiveness of the teaching and learning process so that it leads a tremendous success for the students and increases job satisfaction for the teacher (Weimer, 2002). Besides, students are also trained to grow courage in themselves, especially in asking material they do not understand or expressing their opinions toward certain topic. Furthermore, it is also trained the students' logic skills to think about how they should solve problems in lessons or in real life.

In Indonesia, the implementation of the 2013 curriculum requires the implementation of student-centered learning. To achieve the student-centered learning, the teaching and learning process is supported by the use of scientific approach which consists of five main learning sections such as observation, question, exploration, association, and communication (Kemendikbud, 2012). According to Weimer (2002), the roles of teacher in the student-centered classroom is as "the guide on the side" who is not seeing the students as empty vessels that need to be filled with knowledge but teacher should seeing them as a seeker that should be guided along their intellectual developmental journey. She also stated that in the learning process, the teacher acts as a facilitator, motivator, and assessor. Therefore, the teacher is no longer the sole core of the learning process in delivering the material. Furthermore, there are several learning models suggested by the curriculum to support the implementation of the scientific approach that emphasizes students' activeness. According to Permendikbud (2014), those learning models are Discovery Learning, Inquiry-based learning, Project- 
based learning and Problem-based learning. Those learning models are expected to make students more active, creative, and guide them to find out by themselves rather than to be told by the teacher.

However, sometimes student-centered learning cannot be conducted well as teachers have planned. Some teachers are facing problems in implementing SCL. Teachers are less able to maximize the time available during the teaching and learning process, (Mislinawati and Nurmasyitah, 2018). Furthermore, teachers are difficult to maximize supervision and class management because of students' inactivity in the learning process. Prasetyawati (2016) added that students' interest in asking question is low.

Furthermore, many researchers have been conducted studies related to the implementation of SCL. The first study was conducted by Kumar (2016) to investigate the major challenges teachers and students face in implementing student-centered methods in English classes. The results showed that most of students were not interested in learning through student-centered methods due to different factors, such as lack of interest and confidence, fear, and mother tongue influence.

The second study was conducted by Mckean (2014) which aimed at examining the effects of implementing student-centered learning (SCL) in a college at-risk of a mathematical classroom and how this teaching strategy affects the students' self-efficacy. There were three significant findings of this study. The first finding was that both students and teachers experienced some resistance level when SCL was initially implemented. The second finding was the increased levels of self-efficacy lead the better mathematical performance. The third finding was SCL was not able to raise achievement. Moreover, SCL activities were improved students' confidence levels.

The third study was conducted by Sunzuma et al. (2012) to determine the factors that hinder the implementation of student-centered methods in the teaching and learning of mathematics at the secondary school level. There were found that the constraints included the examination of assessment requirement, language barrier, time factor, resources mainly textbooks, teachers' subject matter content, the size of the classes, and the heavy planning involved.

Concerning this matter, researcher conducted this study intended to investigate the problems that teacher face and the solutions that teacher have to solve the problems when implementing student-centered learning. The result of this study is intended to contribute to the theoretical insights in teaching English as a Foreign Language (EFL), especially for the implementation of Studentcentered Learning. In addition, it also intended to enrich teachers' knowledge about the problems and the solutions in implementing Student-centered Learning so that it can provide ideas and inspiration for the teachers on how to conduct effective Student-Centered Learning in the learning process.

\section{METHODS}

This research is a qualitative study with descriptive method. The research was conducted at SMAN Bali Mandara Singaraja. The subject of the study was an English teacher of SMAN Bali Mandara Singaraja. Moreover, the object of the study was the teacher's problems and solutions in implementing Student-Centered Learning. Two methods had been used in collecting data of the study namely, voice recording and interviewing. Besides, the researcher used some instruments such as the researcher as the main instrument, voice recorder, field note, and interview guide. The data were analyzed using Miles and Huberman (1994) theory in which it consists of data collection, data reduction, data display and conclusion drawing. To make the data valid and reliable, the researcher used methodological triangulation. The methodological triangulation was employed by conducting interview, recording the interview, using field note and cross-checking the data with the interviewee so the data could be examined from the different perspectives to gain the valid data.

\section{RESULTS AND DISCUSSION}

The finding revealed the problems caused by three main causes. Those are problems caused by the students, teacher and also the learning facilities.

The problems that came from students were the lack of students' ability, students' passiveness, and the lack of students' effort in learning. The teacher claimed that those problems faced during the 
implementation of discovery learning, problem-based learning, and project-based learning model. These problems influence how students performed during the learning process. The students became less able to absorb the material. Regarding the students' passiveness and the lack of students' effort in learning, it was in line with Carlile and Jordan (2005) who stated that student-centered learning encourages students to run their activity, to discover and explore the underlying concepts by themselves and actively involved in the learning process to promote deep learning. However, when the students were passive and they did less effort in learning, the purpose of the student-centered learning becomes less targetable. Moreover, this study's findings were also in line with Prasetyawati (2016), who found that students' interest in asking question is low because many students felt reluctant and even did not involve in the discussion. Faridi et al. (2016) also faced the same problems in which he found that teachers had difficulties in encouraging students to actively participate during the teaching and learning process. Furthermore, this finding is closely related to broader research on students' passiveness problem in Asian Countries. According to Sanger \& Gleason (2020), Asian students are often feeling shy, unwilling to ask questions or speak up in the class. It in contrast with Western students' learning style who are independent, self-confident, assertive, willing to ask questions, and explore ways of thinking more (Ho, 2020). Therefore, this problem can be considered as a problem that English teachers often face, which should be resolved immediately.

Besides the problems caused by students, the other problems were caused by the teacher. The first problem was the teacher's difficulty in grouping students heterogeneously. The teacher faced this problem during the implementation of cooperative learning model. Necessarily, students will improve their performance better through the cooperation process with heterogeneous grouping (Zamani, 2016). However, the teacher felt it difficult distributed students heterogeneously in one group. Therefore, sometimes the learning process could not be conducted as the teacher had planned. The second problem was the lack of teacher's assistance in the consultation process. This problem occurred when the teacher implementing project based learning model. Students should do intense communication with the teacher during the creation of the project in order to get constructive feedback and suggestions from the teacher related to their project. However, this activity could not be conducted well because of the large number of students and the lack of time. According to Kennedy (1996) in Qiang and Ning (2011:2), the challenge of teaching in a large class is that it is difficult to control what happens during the learning process. Hayes 1997 as cited in Qiang and Ning (2011:2) declared that one of the problems of teaching in a large class is control problems and the lack of individual attention. This problem also in line with a study which was conducted by Seng (2014), the study revealed that carrying out student-centered activities needed a lot of time.

Furthermore, the problem caused by the facilities was the lack of learning tools. Learning facilities has an essential role in the success of learning. Therefore, adequate learning facilities are essential. However, the teacher had a problem related to the facilities of learning. This problem happened when the teacher implementing project-based learning model, especially when students made a short movie. During the creation of the short movie, students lacked of camera, stabilizer, and tripod. Therefore, this problem made the production of the short movie become inhibited.

To solve those problems above, the teacher offered some solutions. Regarding the students' ability problem, the first step that the teacher did was identifying the students who had the low ability. He identified the factor that influenced it and their behavior by writing it in a journal or notebook. The second, the teacher motivated students personally. The third was doing class management, for example, by placing students with low ability in a place that was easy to monitor. The fourth was by grouping them with students who have higher ability. This action was intended to give the students who had low ability opportunities to learn from the other students who had higher ability. In studentcentered learning, the relationship between students is equal, especially in promoting growth and development (Lim, 2014). The fifth was by giving appreciation for what they have done. Giving motivation and appreciation was intended to make them more confident to learn, especially in doing a better planning project. It is important because the atmosphere of learning should facilitate the exploration of meaning and make students feel safe and accepted in learning (Combs, 1976). 
Concerning the students' passiveness problem, the teacher offered several solutions. The first was related to the students' passiveness in asking a question during the learning process. The teacher used "stick talking" game to make students asked a question. For example, after finished reading a material, every student must prepare one question minimum. Every student who got the stick given by the teacher must be ready to ask a question. Second, in relation to the students' passiveness in exploring the material, the teacher instructed students to find more resources at the library or on the internet related to the material given. The third solution was related to the students' activeness in conducting a consultation with the teacher to discuss the project planning. The first, the teacher would see the students' plan and assessed it based on the planning, process, and final product assessment. When the planning was categorized as good planning, they could continue to the other steps. However, when the students' planning did not meet the minimum score, the teacher then instructed students to revise or replace it. If it did not work, the teacher would move the passive students into the other group which intended to give a positive influence on them. However, if the students could not do the planning and completely did not conduct a consultation with the teacher, the teacher would choose to give an individual task based on their interest. It is in line with what had proposed by McCombs \& Whisler (1997) in which they stated that the learning process is more meaningful for students when the topics are relevant to their interests, lives, needs and when they are actively engaged in understanding, creating, and connecting to knowledge. Combs (1976) revealed three characteristics that teachers must fulfill to make students more active in the learning activities or processes. The first, students must feel accepted and safe. Also, the atmosphere of learning should facilitate students' exploration of meaning. The second, students must be given frequent opportunities to face new information and experiences in searching meaning without the teachers' dominance. The third, new meaning should be acquired by students through the process of personal discovery.

Regarding to students' effort problem, the teacher offered four solutions to solve it. First, the teacher identified the students by taking notes of them and their behavior. Second, the teacher conducted classroom management by grouping them with students who have good effort. Third, the teacher mobilized them to the place that was easy to monitor, for example, instructing them to sit in front. It was in line with a study conducted by Lotfy (2012), who found that students were more confident after experiencing seating arrangement and it was able to foster the students' participation on tasks during the learning process. Fourth, the teacher gave the students a reward. Take, for example; the teacher gave the students appreciation or reward when they tried to explore more information related to the material during the implementation of the discovery learning model or actively expressed their findings during learning with the teacher. Besides, during the implementation of project-based learning, when the students were doing the project well, the teacher appreciated it by giving a good score and announcing their project to the whole class as a good project example. This action was expected to encourage students to be eager and able to follow the learning maximally. It was in line with one of the roles of teacher in student-centered learning in which the teacher should encourage students to do more discovery learning and encourage them to learn more from each other - (Weimer, 2002).

The next solution was related to the teacher's difficulty in grouping students heterogeneously. The implementation of grouping strategies helps students improve their ability and solve English class problems, (Apple, 2006). However, the teacher felt it difficult to grouping students heterogeneously. This problem occurred during the implementation of the cooperative learning model. The teacher's solution was identifying the ability of every student, especially students who have low and high ability. After that, the teacher grouped students who had low and high ability differently. Then, the teacher chose each student with high ability to be the expert or group leader and distributed students with low ability to each leader. After that, the teacher continued distributed the students with average ability equally to each group that had been made before.

Regarding the teacher' lack of assistance, the teacher solution was doing scheduling for the consultation and instructing them to do a discussion with their friend before consulting their project to the teacher. Every student should consult their planning project with the teacher during the 
production of the project. Before consulting their planning to the teacher, the teacher instructed the students to share and discuss their problem with their friend first. If they could not find any solutions from their friend yet, they could continue asking the teacher for the consultation. Besides, the teacher would make a schedule for the students before conducting the consultation. It was expected to make the teacher could assist students in doing the consultation more regularly. It is needed because in student-centered learning teachers have a role as a facilitator in which the role is to clarify and stimulate the students' minds - (Lim, 2014).

Furthermore, in relation to the lack of tools problem during the project based learning implementation, the teacher solution was borrowing the tools from the school facilities section and rotate the tool usage. In planning the project, students would map the tool used for the production of the project. They would discuss the tools that they would use with the teacher. For example, when the students made a short movie, they need a tripod, camera or stabilizer. However, because of the lack of tools at the school, the students must use it in turns with other groups although sometimes it made it took more time to make the project.

\section{CONCLUSION}

Based on the finding and discussion above, it can be concluded that student-centered learning is a challenge for teachers and students. It is inseparable from the problems that arise when implementing student-centered learning. The problems faced by the teacher included problems caused by students, teacher, and the use of facilities to support learning. The teacher' solutions to solve the problems were by identifying the students' ability, motivating students personally, doing the class management well, using "stick talking" game to lead students to ask a question, instructed students to find more resources on the internet or library, giving a reward, instructed students to revise their planning when it was not meeting the minimum score before mobilizing them to the other group or permitting them to choose individual task based on their interest, grouping students evenly based on the identification result, scheduling and instructing them to do a discussion with their friend before consulting their project to the teacher and the last borrowing tools from the school facilities section and rotating the tool usage.

\section{REFERENCES}

Apple, Matthew T. (2006) Language Learning Theories and Cooperative Learning Techniques in the EFL Classroom. Doshisha Society for the Study of Language and Culture.

Carlile, O., \& Jordan, A. (2005). It works in practice but will it work in theory? The theoretical underpinnings of pedagogy. In S. Moore, G. O'neill, \& B. McMullin (Eds.), Emerging Issues in the practice of University Learning and Teacbing, Dublin: AISHE

Chombs, A. W. (1976). Fostering Maximum Development of the Individual. In Learner-Centered Classrooms, Problem-Based Learning, and the Construction of understanding and Meaning by Students. Retrieved December, 12, 2020, from http://www.ncrel.org Web site: http://www.ncrel.org/sdrs/areas/isues/content/cntareas/science/sc3learn.htm

Faridi, A., Bahrim, S. \& Nurmasitah, S. (2016). The Problems of Applying Student Centered Syllabus of English in Vocational High Schools in Kendal Regency. Canadian Center of Science and Education, 9(8), 231 240.

Ho, Shelen. (2020). Diversity and Inclusion in Global Higher Education. Lessons from Across Asia. Singapore: Springer Nature Singapore Pte Ltd.

Kementrian Pendidikan dan Kebudayaan (2012). Dokumen Kurikulum 2013. Retrieved from http://pendidikan-diy.go.id/file/mendiknas/dokumen-kurikulum-2013.pdf

Kumar, M. K. (2016). Challenge in Implementing Student-centered Strategies in Classrooms. International Research Journal of Engineering and Technology (IRJET), 03(12), 1224-1227.

Lim, E., K., S. (2014). Investigating Teachers' Views of Student-Centred Learning Approach. International Education Studies, 7(7). doi: 10.5539/ies.v7n7p143 
Putu Erna Adnyani, I Putu Ngurah Wage Myartawan, I Nyoman Pasek Hadi Saputra

Lotfy, N. (2012). Seating arrangement and cooperative learning activities: Students' on-task/ off-task participation in EFL classrooms. The department of TEFL.

McCombs, B. L., \& Whisler, J. S. (1997). The Learner-Centered Classroom and School: Strategies for Increasing Student Motivation and Achievement. The Jossey-Bass Education Series. San Francisco, CA: JosseyBass Inc.

McKean, S. (2014). The Effects of Implementing Student-centered Learning on At-risk. Students' Self-efficacy. University of Toronto

Miles, M. B., \& Huberman, A. M. (1994). Qualitative Data Analysis (2nd ed.). California: SAGE Publications, Inc.

Mislinawati \& Nurmasyitah (2018). Kendala Guru Dalam Menerapkan Model-Model Pembelajaran Berdasarkan Kurikulum 2013 Pada SD Negeri 62 Banda Aceh. Jurnal Pesona Dasar, 6(2), 22-32

Prasetyawati, P. (2016). Analisis Proses Pembelajaran Berbasis Student Centered Leaning Dalam Pendekatan Saintifik Pada Mata Pelajaran Sejarah Di SMA Negeri Se Kota Palu. E Jurnal Katalogis, 4(10), 130-137

Qiang, Wang and Ning, Zhang (2011). Teaching Large Classes in China-English as a Foreign Language. Beijing Normal University: China

Sanger, C., S. \& Gleason, N., W. (2020). Diversity and Inclusion in Global Higher Education. Lessons from Across Asia. Singapore: Springer Nature Singapore Pte Ltd.

Seng, E., L., K. (2014). Investigating Teachers' Views of Student-Centred Learning Approach. International Education Studies, 7(7). doi: 10.5539/ies.v7n7p143

Sunzuma, G., Ndemo, Z. \& Zezekwa, N. (2012). The Challenge of Implementing Student-centered Instruction in the Teaching and Learning of Secondary School Mathematics in a Selected District in Zimbabwe. Computer Science, Mathematics.

Weimer, M. (2002). Learner-centered teaching: Five key changes to practice. San Francisco, CA: Jossey-Bass

Zamani, Mona. (2016). Cooperative Learning: Homogeneous and Heterogeneous

Grouping of Iranian EFL Learners in a Writing Context. Cogent Education. Available online at http://dx.doi.org/10.1080/2331186X.2016.1149959 